
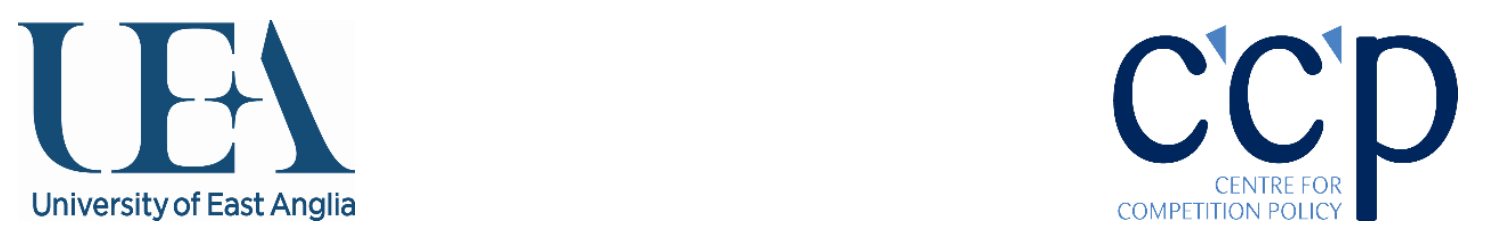

\title{
Three forms of BT Separation: Objectives, solutions and effects
}

\author{
Richard Cadman \\ Director, SPC Network Ltd
}

CCP Working Paper 16-10

\begin{abstract}
Following its latest strategic review of the digital communications sector, Ofcom has proposed that BT's access services division, Openreach, becomes a subsidiary of BT plc. BT has put forward a counter proposal it terms Enhanced Functional Separation. This paper reviews the two proposals and compares them with the current situation. It finds that the differences between BT's and Ofcom's proposals are less substantive that might appear at first sight. The paper also considers the whether the incentives for BT to invest in taking fibre access networks closer to the customer are likely to be any different under the two proposals. Again, the paper is sceptical that the legal separation proposed by Ofcom would result in greater incentives than would occur under Enhanced Functional Separation.
\end{abstract}

Contact Details:

Richard Cadman richard.cadman@spcnetwork.eu 


\title{
Three forms of BT Separation: Objectives, solutions and effects
}

\author{
Dr Richard Cadman
}

Director, SPC Network Ltd. ${ }^{1}$

\section{DRAFT 20160907}

\begin{abstract}
Following its latest strategic review of the digital communications sector, Ofcom has proposed that BT's access services division, Openreach, becomes a subsidiary of BT plc. BT has put forward a counter proposal it terms Enhanced Functional Separation. This paper reviews the two proposals and compares them with the current situation. It finds that the differences between BT's and Ofcom's proposals are less substantive that might appear at first sight. The paper also considers the whether the incentives for BT to invest in taking fibre access networks closer to the customer are likely to be any different under the two proposals. Again, the paper is sceptical that the legal separation proposed by Ofcom would result in greater incentives than would occur under Enhanced Functional Separation.
\end{abstract}

\section{Introduction}

In 2005 the UK telecoms regulator, Ofcom conducted the Telecoms Strategic Review (TSR) the final outcome of which was a set of Undertakings agreed with BT. These required BT to establish a separate operating division, Openreach, that would supply key access products to all Communications Providers, including BT's own retail businesses: a structure known as "Functional Separation". Ten years later, Ofcom has conducted its Strategic Review of Digital Communications (DCR) and has concluded that further separation of Openreach is required and that what is currently an operating division should become a subsidiary of BT Group with various behavioural

\footnotetext{
${ }^{1}$ The author is also an Associate member of the Centre for Competition Policy at the University of East Anglia
} 
constraints built into its Articles of Association. BT has countered with its own proposal for "Enhanced Functional Separation", leaving Openreach as a division of BT.

In all cases, the separation of BT is a means to an end, designed to protect those of BT's retail competitors who rely on BT's access network from market foreclosure by price or non-price discrimination (Cadman 2010). In so doing, the structure of BT and the behavioural constraints imposed on it were, and are, expected to improve outcomes for BT's competitors and, ultimately, consumers of all firms in the market.

This paper compares and contrasts the three forms of separation and seeks to assess how effective each would be at achieving their objectives. The paper is organised as follows. Section 2 sets the industry and economic context within which the various proposals are made. Section 3 compares and contrasts functional, enhanced functional and legal separation. Section 4 assesses how Ofcom's proposal and BT's counter proposal are likely to meet Ofcom's objectives as set out in the DCR. Section 5 concludes.

\section{Industry and Economic Context}

The UK telecommunications sector, like those in other countries, is characterised by a vertically integrated former incumbent operator that provides an essential input (access) to its retail rivals. BT competes at the retail level with broadband operators such as Sky and TalkTalk, but also provides those firms with wholesale access services, in particular unbundled local loops and Virtual Unbundled Local Access (VULA), its wholesale fibre to the cabinet product.

This industry structure is well known to bestow on the vertically integrated firm both the incentives and the ability to discriminate against its downstream rivals (Beard et al 2001, Rey \& Tirole 2007).

In essence, the fact that rivals are reliant on the vertically integrated firm for an upstream, or wholesale, input means that, in most circumstances, the vertically 
integrated would prefer to harm its rivals, through price or non-price discrimination, than treat them in the same way as it treats its own retail division. The incentive increases if the vertically integrated firm's upstream prices are regulated to its marginal cost meaning that it can only increase profits by increasing it retail market share (Mandy \& Sappington 2007). Conversely, the incentive reduces if the vertically integrated firm earns greater profits from its wholesale operations than from its retail business (Mandy 2000). Under the single monopoly profit theory the vertically integrated firm would have no incentive to discriminate against its downstream rivals if it were able to set the monopoly price, and earn monopoly profits, for the essential input provided that the downstream market was competitive (Riordan 2008).

Regulators have, unsurprisingly, fought shy of using the single monopoly profit theory to deter discrimination against retail rivals. No regulator would like the wholesale price to be set at the monopoly level with consequent reductions in consumer welfare. Rather, they have imposed various forms for separation between the upstream, monopolistic, part of the vertically integrated firm and downstream businesses that operate in competitive, or potentially competitive, markets. Cave (2006) identified six degrees of separation between accounting, the least intrusive, and structural, the most intrusive, separation.

With the exception of structural separation, the various degrees identified by Cave keep the vertically integrated firm in tact and so do not change its fundamental incentive to discriminate against its rivals. However, separation does alter the firm's ability to discriminate by ensuring a greater level of transparency on transactions between the upstream and downstream businesses (Cave and Martin 1994). The vertically integrated firm's incentive to discriminate could be reduced if the likelihood of it being caught so doing and the sanctions imposed outweigh the benefits from discrimination.

Accounting separation, in which the integrated firm has to produce separate accounts for the upstream business, is the most common form of separation and is used by most regulators. However, it is designed primarily to deter price discrimination and 
leaves the vertically integrated able to use non-price means to harm rivals. Some regulators have gone further and introduced other forms of regulation to address concerns about non-price discrimination. Thus Telecom Italia (Italy) and Telia (Sweden) are subject to more intrusive forms of regulation. New Zealand Telecoms has now been structurally separated into Chorus (upstream) and Spark (downstream) as two completely independent firms, following a period of functional separation. However, it should be noted that structural separation was not introduced primarily to remove the incentive for non-price discrimination, but to allow Chorus to access state funds for the development of a fibre to the home network.

\section{Ofcom's Strategic Reviews: Comparison of Outcomes}

\subsection{Strategic Review Proposals}

When Ofcom conducted its TSR in 2004/2005 it became concerned that BT had both the incentive and ability to harm its rivals. Several of BT's rivals made this point to Ofcom in influential submissions (Cadman 2010). Even though BT had never been found guilty of so doing (Cave 2006), the expectation that it would behave in such a way was enough to change rivals' behaviour leading to a sub-optimal outcome for investment, competition and consumers. Ofcom concluded that operators who rely on BT for access 'have experienced twenty years of:

- Slow product development;

- Inferior quality wholesale products;

- Poor transactional process; and

- A general lack of transparency' (Ofcom 2004, Para. 1.19)

To address this concern, Ofcom agreed a set of Undertakings with BT under which BT accepted certain behavioural and structural changes. The behavioural change was defined in the Undertakings as Equivalence of Input (EOI). This required BT to provide all CPs, including its own downstream business, with the same products on the same 
timescales, terms and conditions by means of the same processes and to provide the same commercial information (Ofcom 2005, p61). EOI was a means of strengthening the existing obligation of "no undue discrimination" already imposed on BT in markets where it was found to have Significant Market Power (SMP).

The organisational changes agreed between Ofcom and BT were known as, although not defined in the Undertakings as, "Functional Separation" (FS). The Undertakings required BT to establish a separate "Access Services" division, later branded as Openreach ${ }^{2}$. The details of the separation will be discussed below.

Ofcom launched its second strategic review in 2015 (Ofcom 2015), this time broadening the scope of the review to digital communications in general, rather than telecommunications. In its initial findings (Ofcom 2016a), Ofcom continued to express concern that the market was not working as effectively as it could and that BT's structure and behaviour were contributory factors. It stated that "BT continues to have the ability and incentive to favour its downstream business in certain respects. Therefore risks to competition remain" (Ofcom 2016a, Para. 6.22). Ofcom highlighted four specific concerns raised by stakeholders:

- Strategic decision making;

- Consultation with customers;

- Governance and operational independence of Openreach; and

- Cost allocation between Openreach and the rest of BT.

In its later proposal for strengthening Openreach's independence, Ofcom accepted that BT was prevented from supplying inferior products and services to its competitors, but that it still had the ability to discriminate "when making key decisions that shape the network itself" (Ofcom 2016b, Para 3.12).

To counter these market weaknesses, Ofcom is now proposing that Openreach is established as a separate limited company, within the BT group but with various

\footnotetext{
${ }^{2}$ From hereon the Access Service division created by the Undertakings will be referred to as Openreach.
} 
behavioural constraints built in to its Articles of Association (Ofcom 2016b). Ofcom's proposal equates to legal separation (LS), as defined by Cave (Cave 2006) and will be explored in detail below.

BT has made its own counter proposal for what it refers to as "enhanced functional separation" (EFS) in a document submitted to Ofcom in July 2016 (BT 2016). BT's proposal sits somewhere between the status quo of FS and the LS proposed by Ofcom. Although it contains many of the features proposed by Ofcom, Openreach would remain an operating division of BT rather than a separate subsidiary.

Figure 1 summaries the market problems identified by Ofcom and the solutions put forward by Ofcom and BT.

Figure 1: Problems and Summary of Proposals

\begin{tabular}{|c|c|c|}
\hline Proposer/Year & Identified Problems & Solution \\
\hline Ofcom 2005 & $\begin{array}{l}\text { - Non-price discrimination } \\
\text { - Poor quality of service }\end{array}$ & $\begin{array}{l}\text { - Equivalence of Input } \\
\text { - "Functional Separation" }\end{array}$ \\
\hline Ofcom 2016 & $\begin{array}{l}\text { - Continued discrimination } \\
\text { with regard to product } \\
\text { development - new } \\
\text { products designed for BT } \\
\text { not rivals } \\
\text { - Continued poor quality } \\
\text { of service } \\
\text { - Lack of investment, } \\
\text { specifically in fibre }\end{array}$ & $\begin{array}{l}\text { - Legal separation of } \\
\text { Openreach within BT } \\
\text { Group } \\
\text { - Behavioural constraints } \\
\text { on Openreach through } \\
\text { Articles of Association } \\
\text { - Greater independence of } \\
\text { Openreach investment } \\
\text { decisions within } \\
\text { "financial envelope" } \\
\text { granted by BT Group }\end{array}$ \\
\hline BT 2016 & $\begin{array}{l}\text { BT rejects problems but } \\
\text { notes concerns raised in } \\
\text { the DCR }\end{array}$ & $\begin{array}{l}\text { - Enhanced "Functional } \\
\text { Separation" } \\
\text { - Behavioural constraints } \\
\text { through BT Group } \\
\text { Articles of Association. }\end{array}$ \\
\hline
\end{tabular}




\subsection{Comparison of Objectives and Proposals}

The table set out on the following pages describes FS, EFS and LS in further detail breaking down each proposal into a number of key criteria: objectives; equality of treatment obligation; the legal status of Openreach; oversight of Openreach; employee status; consultation with customers; financial control; ownership of Openreach assets; and branding \& identity. 


\begin{tabular}{|c|c|c|c|}
\hline & Functional Separation & Legal Separation & Enhanced Functional Separation \\
\hline Objective & $\begin{array}{l}\text { - Reduce incentives and ability for } \\
\text { BT to foreclose retail markets } \\
\text { through non-price discrimination } \\
\text { - Improve Quality of Service }\end{array}$ & $\begin{array}{l}\text { Reduce incentives and ability for } \\
\text { BT to foreclose retail markets } \\
\text { through non-price discrimination. } \\
\text { In particular through BT making } \\
\text { investment decisions that favour } \\
\text { its own downstream businesses } \\
\text { - Improve Quality of Service } \\
\text { - Increase availability of fibre based } \\
\text { broadband }\end{array}$ & $\begin{array}{l}\text { BT does not accept Ofcom has provided } \\
\text { evidence of significant competition } \\
\text { problems. However, it does recognise } \\
\text { need to respond to growing demands } \\
\text { and expectations of customers, } \\
\text { particularly in relation to service. }\end{array}$ \\
\hline $\begin{array}{l}\text { Equality of } \\
\text { treatment } \\
\text { obligation }\end{array}$ & $\begin{array}{l}\text { Requirement to provide specific } \\
\text { services under "Equivalence of Input" } \\
\text { (EOI): same product under same terms } \\
\text { and in same timescales to all CPs, } \\
\text { including BT's downstream divisions. }\end{array}$ & $\begin{array}{l}\text { Requirement to treat customers equally } \\
\text { built into Articles of Association (see } \\
\text { below). Ofcom does not mention what } \\
\text { happens to EOI. }\end{array}$ & $\begin{array}{l}\text { EOI obligation removed from revised } \\
\text { Undertakings and to be imposed } \\
\text { through obligations imposed on BT in } \\
\text { markets where it has SMP. Requirement } \\
\text { on BT Group and Openreach to treat all } \\
\text { customers equally written into revised } \\
\text { BT plc Articles of Association (see } \\
\text { below). }\end{array}$ \\
\hline $\begin{array}{l}\text { Legal Status } \\
\text { and purpose } \\
\text { of } \\
\text { Openreach }\end{array}$ & Division of BT. & $\begin{array}{l}\text { Separate Subsidiary. Separate Articles of } \\
\text { Association to state that core purpose of } \\
\text { company is to serve all customers } \\
\text { equally. Company Directors will have a } \\
\text { duty to act accordingly under UK } \\
\text { company law. Articles also to require }\end{array}$ & $\begin{array}{l}\text { Division of BT. } \\
\text { BT plc's Articles of Association to be } \\
\text { amended to allow for the creation of an } \\
\text { Openreach Board as a committee of the } \\
\text { BT plc Board. Articles of Association will } \\
\text { also place an obligation on the BT }\end{array}$ \\
\hline
\end{tabular}




\begin{tabular}{|c|c|c|c|}
\hline & & $\begin{array}{l}\text { that Directors comply with regulatory } \\
\text { obligations. }\end{array}$ & $\begin{array}{l}\text { Group Board and the Openreach Board } \\
\text { to treat all customers equally. }\end{array}$ \\
\hline Oversight & $\begin{array}{l}\text { Equivalence of Access Board (EAB). The } \\
\text { EAB to consist of five people: three } \\
\text { independent members. One BT Group } \\
\text { Non Executive Director (NED) and one } \\
\text { senior BT manager. The BT Group NED } \\
\text { acts as Chair who shall appoint the } \\
\text { three NEDs following agreement with } \\
\text { the BT Group Chair and Ofcom. The role } \\
\text { of the EAB is one of monitoring, } \\
\text { reporting and advising BT on BT's } \\
\text { compliance with the Undertakings and } \\
\text { the Code of Practice (see below) with a } \\
\text { specific focus on the provision of } \\
\text { products on an EOI basis and the } \\
\text { operation of Openreach. }\end{array}$ & $\begin{array}{l}\text { Company Board. The Board to consist of } \\
\text { an independent Chair along with three } \\
\text { independent NEDs and a BT Group NED. } \\
\text { In addition the CEO of Openreach and } \\
\text { another Openreach executive would } \\
\text { serve on the Board. The appointment } \\
\text { and removal of Directors would be } \\
\text { carried out by BT Group in consultation } \\
\text { with Ofcom. The Openreach Board } \\
\text { would appoint the Openreach CEO with } \\
\text { no involvement from BT, Ofcom or } \\
\text { other telecoms companies. The } \\
\text { Openreach CEO would report to the } \\
\text { Openreach Board only and there would } \\
\text { be no direct reporting lines between the } \\
\text { Openreach CEO or other Openreach } \\
\text { executives and BT Group executives. }\end{array}$ & $\begin{array}{l}\text { The EAB to be replaced by an } \\
\text { Openreach Board to consist of: an } \\
\text { independent Chair appointed by BT } \\
\text { Group, in consultation with Ofcom; } \\
\text { three independent NEDs; a BT Group } \\
\text { appointed nominee; the Openreach } \\
\text { CEO; and another Openreach executive. }\end{array}$ \\
\hline $\begin{array}{l}\text { Employee } \\
\text { status }\end{array}$ & $\begin{array}{l}\text { People who work in Openreach remain } \\
\text { employees of BT Group. However, BT } \\
\text { required to produce a Code of Practice } \\
\text { for employees to ensure they } \\
\text { understand their obligations as set out } \\
\text { in the Undertakings. }\end{array}$ & $\begin{array}{l}\text { Ofcom's "strong preference" is for all } \\
\text { people who work in Openreach to be } \\
\text { employees of the new company rather } \\
\text { than of BT Group. Where it is not } \\
\text { possible or where costs are } \\
\text { disproportionate Ofcom is open to } \\
\text { exploring alternative arrangements. }\end{array}$ & $\begin{array}{l}\text { Remain employees of BT. All BT } \\
\text { employees to be made aware of a Code } \\
\text { of Practice setting out obligations under } \\
\text { the Undertakings. }\end{array}$ \\
\hline
\end{tabular}




\begin{tabular}{|c|c|c|c|c|}
\hline $\begin{array}{l}\text { Consultation } \\
\text { with } \\
\text { customers }\end{array}$ & $\begin{array}{l}\text { Openreach is required to establish a } \\
\text { "Statement of Requirements" process } \\
\text { to consider new network access } \\
\text { products requested by customers, } \\
\text { including BT. It is free to accept or } \\
\text { reject such requests. } \\
\text { A multilateral industry group, including } \\
\text { BT, to be established to agree on the } \\
\text { transition from PSTN to NGN networks. }\end{array}$ & $\begin{array}{l}\text { A form } \\
\text { custom } \\
\text { consist } \\
\text { i) }\end{array}$ & $\begin{array}{l}\text { orocess to consult with } \\
\text { on investment plans } \\
\text { of three main elements: } \\
\text { An obligation to consult } \\
\text { formally on major } \\
\text { investments in networks and } \\
\text { products before decisions to } \\
\text { invest are made: } \\
\text { A 'confidential' engagement } \\
\text { phase where customer can } \\
\text { discuss investment ideas } \\
\text { without information being } \\
\text { disclosed outside Openreach, } \\
\text { except with the consent of } \\
\text { the customer. } \\
\text { Downstream divisions of BT } \\
\text { would use the same process } \\
\text { to initiate major new } \\
\text { investments. BT Group would } \\
\text { not be able to initiate } \\
\text { investments outside this } \\
\text { process. }\end{array}$ & $\begin{array}{l}\text { Openreach to operate a formal process } \\
\text { for consulting with customers in the } \\
\text { early stage of any significant investment } \\
\text { decision relating to the development or } \\
\text { the network. The process will consist of: } \\
\text { i) A confidential phase; } \\
\text { ii) A public phase; and } \\
\text { iii) A committed phase. } \\
\text { During the confidential phase, CPs can } \\
\text { discuss investment ideas with } \\
\text { Openreach without this information } \\
\text { being disclosed except (i) with the } \\
\text { consent of the CP or (ii) where } \\
\text { Openreach considers a proposal to be of } \\
\text { significant strategic importance that } \\
\text { cannot be financed within the agreed } \\
\text { capital expenditure budget of } \\
\text { Openreach. } \\
\text { Downstream divisions of BT will use the } \\
\text { same process to initiate investment } \\
\text { proposals. }\end{array}$ \\
\hline $\begin{array}{l}\text { Financial } \\
\text { Control }\end{array}$ & $\begin{array}{l}\text { Openreach to establish an annual } \\
\text { operating plan and submit to BT Group } \\
\text { Board for approval. The Openreach CEO } \\
\text { to have delegated authority for capital }\end{array}$ & \multicolumn{2}{|c|}{$\begin{array}{l}\text { BT Group to retain oversight through } \\
\text { the setting of a 'financial envelope' } \\
\text { containing high level metrics for } \\
\text { revenues, operating expenditure, capital } \\
\text { expenditure, profitability and cash flow. }\end{array}$} & $\begin{array}{l}\text { The Openreach executive to produce an } \\
\text { annual medium term plan and budget } \\
\text { (MTP), including a detailed annual } \\
\text { operating plan (AOP) and budget for the } \\
\text { first year. The MTP and AOP will be }\end{array}$ \\
\hline
\end{tabular}




\begin{tabular}{|c|c|c|c|}
\hline & $\begin{array}{l}\text { expenditure of up to } f 75 \text { million within } \\
\text { the annual plan. }\end{array}$ & $\begin{array}{l}\text { Within the envelope, Openreach would } \\
\text { set its own priorities "in the interests of } \\
\text { all its customers". Openreach executives } \\
\text { would develop a medium-term strategic } \\
\text { plan containing a committed strategy } \\
\text { and budget for the first year. The } \\
\text { Openreach Board would decide the } \\
\text { exact nature of these plans. A high level } \\
\text { summary would be shared with the BT } \\
\text { Group Board. Where major investment } \\
\text { plans fall outside the envelope the } \\
\text { Openreach Board would recommend } \\
\text { these to the BT Group Board. }\end{array}$ & $\begin{array}{l}\text { submitted to the BT Group CEO and CFO } \\
\text { for review and high level summaries will } \\
\text { be submitted to the BT Group Board for } \\
\text { approval. They will also be submitted to } \\
\text { the Openreach Board for review and } \\
\text { approval. }\end{array}$ \\
\hline $\begin{array}{l}\text { Openreach } \\
\text { Assets }\end{array}$ & $\begin{array}{l}\text { Openreach controls and operates assets } \\
\text { in the physical layer of the access and } \\
\text { backhaul networks, but does not have } \\
\text { ownership of these assets. }\end{array}$ & $\begin{array}{l}\text { Preference for transferring network and } \\
\text { associated electronic assets to } \\
\text { Openreach. Starting point to transfer } \\
\text { those assets Openreach controls under } \\
\text { FS. However, Ofcom willing to consider } \\
\text { alternative methods if costs of transfer } \\
\text { and affects on BT Group's financial } \\
\text { position disproportionate. }\end{array}$ & $\begin{array}{l}\text { Openreach controls and operates assets } \\
\text { in the physical layer of the access and } \\
\text { backhaul networks, but does not have } \\
\text { ownership of these assets. }\end{array}$ \\
\hline $\begin{array}{l}\text { Brand and } \\
\text { Identity }\end{array}$ & $\begin{array}{l}\text { Openreach to be a separate brand not } \\
\text { incorporating the elements BT or British } \\
\text { Telecom but used in proximity to an } \\
\text { endorsement containing the words "A } \\
\text { BT Group business (and BT corporate } \\
\text { device)". Openreach to be located in } \\
\text { separated premises. }\end{array}$ & $\begin{array}{l}\text { Openreach should have its own brand } \\
\text { not associated with BT. }\end{array}$ & $\begin{array}{l}\text { Openreach to be a separate brand not } \\
\text { incorporating the elements BT or British } \\
\text { Telecom but used in proximity to an } \\
\text { endorsement containing the words "A } \\
\text { BT Group business (and BT corporate } \\
\text { device)". Openreach to be located in } \\
\text { separated premises. }\end{array}$ \\
\hline
\end{tabular}




\subsection{Similarities and Differences}

The table below sets out the similarities and differences between the three models of separation.

\section{Figure 2: Comparison of Characteristics of Separation Proposals}

\begin{tabular}{|c|c|c|c|c|}
\hline $\begin{array}{c}\text { Functional Separation } \\
\text { Only }\end{array}$ & $\begin{array}{l}\text { Enhanced Functional } \\
\text { Separation only }\end{array}$ & Legal Separation only & $\begin{array}{l}\text { Functional and Enhanced } \\
\text { Functional Separation }\end{array}$ & $\begin{array}{c}\text { Enhanced Functional and } \\
\text { Legal Separation }\end{array}$ \\
\hline $\begin{array}{l}\text { - } \text { EOI obligation in } \\
\text { undertakings } \\
\text { - Oversight by EAB } \\
\text { - Composition of EAB } \\
\text { - SOR Process } \\
\text { - AOP and f75million } \\
\text { capex limit }\end{array}$ & $\begin{array}{l}\text { - MTP and AOP } \\
\text { approved by BT } \\
\text { Group CEO and } \\
\text { CFO }\end{array}$ & $\begin{array}{l}\text { - Openreach as a } \\
\text { subsidiary } \\
\text { - Employees of } \\
\text { Openreach } \\
\text { - Openreach } \\
\text { ownership of assets } \\
\text { - Financial envelope } \\
\text { granted by BT } \\
\text { Group } \\
\text { - Separate branding }\end{array}$ & $\begin{array}{l}\text { - Openreach as a } \\
\text { division of BT } \\
\text { - Employees of BT } \\
\text { Group } \\
\text { - Code of Practice for } \\
\text { employees } \\
\text { - BT ownership of } \\
\text { assets } \\
\text { - Openreach brand } \\
\text { with BT device }\end{array}$ & $\begin{array}{l}\text { - Equal treatment } \\
\text { imposed through } \\
\text { articles of } \\
\text { association. } \\
\text { - Oversight by } \\
\text { Openreach Board } \\
\text { - Openreach Board } \\
\text { composition } \\
\text { - Consultation } \\
\text { process with } \\
\text { customers }\end{array}$ \\
\hline
\end{tabular}


Perhaps the most important difference between the LS and EFS is that the LS proposal put forward by Ofcom is structurally quite different from either FS or EFS in that Openreach would become a separate company, albeit one within the BT Group. Ofcom expects that this "inherently more independent" structure will give "the right incentives and sufficient authority for the Openreach Board to take decisions that are not influenced by the wider interest of BT Group" (Ofcom 2016b, Para 4.4 \& 4.5). As a separate company, Openreach would have its own employees and its own assets, or at least that would be Ofcom's preferred outcome. Customers of Openreach would contract with Openreach rather than with BT plc as they do currently.

BT's view is that such legal separation is unnecessary and that maintaining the vertically integrated structure of the company "supports continued investment in the access network" and that "it is a recognised benefit that a vertically-integrated Communications Provider considering network investment can factor in the margins made at the retail level" (BT 2016, Para. 27).

Although these two approaches are structurally different, there are strong similarities between the governance arrangements proposed by Ofcom and BT. Each proposes an Openreach Board with strikingly similar structures, although one would be a Board of Directors of Openreach Ltd and the other a committee of the BT plc Board. Also, in both cases an obligation to treat all customers equally would be written into the Articles of Association: in Ofcom's proposal the Articles of Association of Openreach Ltdand in BT's proposal those of BT plc.

Although not mentioned in either proposal, it is of course the case that were BT or Openreach found to have SMP in a relevant market and thus had obligations imposed by Ofcom to prevent abuse of the market power, BT plc and its Openreach division or subsidiary would be subject to those legal obligations.

Another apparent difference between the Ofcom and BT proposals is the financial freedom of Openreach. Ofcom's proposal foresees Openreach being granted a 'financial envelope' and for it to have discretion over capital expenditure and 
investment. The financial envelope would contain high-level performance metrics, but Openreach would independently develop its own priorities, in the interests of customers, within that envelope.

By contrast, BT's proposal is that Openreach presents the BT CEO and CFO with a MTP that sets out its priorities and that this plan is then agreed with BT.

In practice, it seems that there is little difference between the two approaches. Ofcom's proposal appears top-down and BT's bottom-up, in that the former grants money to Openreach and the latter responds to a request, but it seems likely that this would make little difference to the priorities of Openreach. Either way, it is for Openreach to determine, in consultation with its customers, how and where to invest in network developments.

The differences in structure appear to be overcome by similarities in oversight and the powers of the Openreach Board and executive that mean such difference are minimised.

\section{$4 \quad$ Incentives for Investment}

In the DCR Ofcom has highlighted the need for further investment by CPs in the rollout of fibre broadband access to provide higher access speeds for consumers (Ofcom 2016a, Section 4). Ofcom expects that a more independent Openreach will support new models of investment in communications networks and will enable further differentiation of communications services for consumers and businesses (Ofcom 2016b, Para 3.3). Ofcom's view is that SMP obligations and Undertakings prevent BT from supplying inferior products to other CPs, but "do not limit the ability of BT to discriminate when making key decisions that shape the network itself" (Ofcom 2016b Para. 3.12). In other words, BT can still make investment decisions that favour its own downstream businesses over its rivals. 
In assessing the relative merits of the alternative forms of separation proposed by BT and Ofcom, then, it becomes appropriate to explore whether Openreach's investment incentives would be significantly different under the two approaches.

At its simplest, a firm would choose to invest its shareholders' capital if the expected return on the investment (ROI) is equal to or, preferably, greater than the weighted average cost of that capital (WACC). Thus before any investment is made the following minimum threshold must be expected:

$$
R O I \geq W A C C
$$

If presented with two investment choices, in say project $A$ and project $B$, the firm will choose to invest in the project with the higher ROI, provided both meet the basic threshold. Thus the firm will choose project $A$ if:

$$
R O I_{A}>R O I_{B} \geq W A C C
$$

The firm will be indifferent between the two projects if the expected ROI is the same for them both.

Where a firm is vertically integrated and required to provide access to the upstream input to its downstream rivals this simple assessment may become more complex. This is because the firm's decision may be based not only on the ROI it expects directly, but also on the effect on its rivals. In other words, the vertically integrated firm (VIF) may choose its investment option strategically.

Suppose that the VIF has a choice between two investments ( $A$ and $B$ ), both of which are expected to generate an economic profit. Option A favours its own downstream business over its rivals and Option B benefits all downstream firms, including the VIF's own downstream business, equally. We can now envisage three conditions:

Condition 1: $\quad R O I_{A}>R O I_{B}$ 
Condition 2: $\quad R O I_{A}=R O I_{B}$

Condition 3: $\quad \mathrm{ROI}_{A}<R O I_{B}$

If the VIF is unconstrained by an obligation such as the one proposed by both BT and Ofcom to treat all customers equally, it would always choose A over B under Condition 1 , as it is clearly in its own interests to do so. It would also be likely to choose A over B under Condition 2 as it would prefer to benefit its own downstream arm rather than its rivals.

How it would choose to invest under Condition 3 probably depends on the difference in the expected ROI. If it is small enough, the firm may still choose $A$ and accept a lower ROI in the short term to favour its own downstream business in the longer term. However if the difference were large enough, then it would be more likely to choose B.

Now let us assume that an obligation to treat all customers equally is a statutory duty of the VIF, as proposed by both BT and Ofcom. The situation with regard to Conditions 2 and 3 would be reversed. Such an obligation would require the firm to choose B over A where there is an advantage to choosing B or where it would be indifferent between the two.

The situation with regard to Condition 1 however is now more complex. An optimistic supporter of the proposed requirement to treat all customers equally may expect that the VIF would have to choose $B$, as otherwise it would be favouring its own downstream business over its rivals and so in breach of the obligation. A more pessimistic view is that the VIF would persuade the regulator to allow it to make an investment that favours itself if the alternative is that it makes no investment at all and that the investment benefits consumers.

Let us now consider these conditions in relation to two potential developments by BT that involve pushing fibre closer to the customer: fibre to the distribution point (FttD) and fibre to the premises (FttP). The former is referred to by BT as G.Fast and appears 
to be BT's favoured technology for extending fibre beyond the cabinet. FttD leaves BT with some control over the final connection from the distribution point to the customer premises and so may be considered as favouring BT over its rivals. By contrast FttP would mean all wholesale customers have the same level of control and so treats all customers equally.

Further, suppose that both investment options meet the threshold condition of having an expected ROI greater than the WACC, and the WACC is the same for both investments (a condition we shall relax later). Let us now apply Conditions 1 and 2 above:

Condition 4

$$
\left(R O I_{D}-W A C C_{D}\right)>\left(R O I_{P}-W A C C_{P}\right)
$$

Condition 5

$$
\left(R O I_{D}-W A C C_{D}\right)=\left(R O I_{P}-W A C C_{P}\right)
$$

Under both BT's and Ofcom's proposal, Openreach would be required to invest in FttP under Condition 5, assuming that the BT Board has approved sufficient funds for Openreach. If Condition 4 applied, the situation may change. If Openreach were to invest in FttP it would be choosing an investment that is less beneficial to its own business than the alternative, regardless of the effect on BT's retail business. Could Openreach be required to make such a decision? Would BT allow Openreach to make this decision given that it would "have visibility of major investment or operational decisions that could have a material bearing on BT Group finances" and when the BT Group Board would have ultimate authority to decide whether to proceed with such investments (Ofcom 2016b, Para 4.54)? Openreach is utility part of BT's business, that is supposed to have a low risk profile and so could it really be asked to invest in the riskier of two projects?

Let us now consider a variation on the above. Suppose that the WACC $\mathrm{p}$ is higher than WACC $C_{D}$, perhaps reflecting a higher degree of risk associated with FttP, but that the margin between the ROI and the WACC were the same. This can be presented as 
Condition $6 \quad\left(R O I_{D}-W A C C_{D}\right)=\left(R O I_{P}-W A C C_{P}\right) \quad W A C C_{P}>W A C C_{D}$

In these circumstances, could Openreach be required to invest in a network development that treated all customers equally, but was inherently more risky than the alternative?

As noted above, Ofcom argues that its proposals will open up opportunities for new forms of investment (Ofcom 2016b, Para 3.3). This has widely been assumed to include some firm of risk-sharing or co-investment between Openreach and CPs. To suggest a hypothetical example, Openreach shares the investment in further FttH with Sky and/or TalkTalk in a specific geographic area.

Whether this may happen or not is unknown. However, it is sensible to consider the likelihood of this happening. Risk sharing also means reward sharing and so is not cost free. As a general rule, investors are willing to share those rewards if they are capital constrained and simply do not have, or cannot get access to, sufficient capital to make the investment within their portfolio. If the return on a particular investment is likely to be positive and greater than the capital required, it would be rational not to share the rewards, if at all possible. Given the size of BT, and its position as one of the largest UK companies by market capitalisation, it is unlikely to be severely capital constrained. Thus we might expect that Openreach would prefer to invest in a project exclusively if the project makes commercial sense. If it does not make commercial sense, it would be no more likely to co-invest that to invest by itself.

Let us now turn to the final question: Would investment be any more likely under EFS and LS, i.e. under the BT or Ofcom proposals? It is not obvious why that would be the case. The Ofcom model may grant Openreach somewhat more independence than the BT proposal, but it does not affect the fundamental conditions under which any firm would invest. The relationship between Openreach and the rest of BT will not affect demand or cost conditions or the risk associated with any investment. The ROI Openreach would achieve on any investment and the cost of capital are likely to be 
unaffected by the structure of BT, so there are no fundamental changes in the investment incentives.

\section{Conclusion}

This paper has compared the two proposals for the further separation of Openreach from the rest of BT put forward by Ofcom and by BT itself. It has shown that the substantive differences between the two are limited. Although Ofcom proposes that Openreach should be a subsidiary company within the BT Group, the governance arrangements and financial independence for Openreach proposed by both parties mean the degree of differences is not as large as may appear on first sight. It is the case that Ofcom's proposals grant Openreach more autonomy that BT's but only within the financial envelope, which is itself set by BT Group and includes financial targets and limits.

The paper has then gone on to consider whether Openreach's incentives to invest and to use new investment models, such as co-investment, are substantially different under the two proposals. The paper is sceptical that there is any significant difference in investment incentives between the two models of separation. It argues that neither the expected return on, nor the cost of, capital are likely to be different under the two proposals and thus neither is more likely that the other to achieve Ofcom's objective of increasing investment in fibre access networks. 


\section{$\underline{\text { References }}$}

Beard, T. Randolph, David L. Kaserman, and John W. Mayo. "Regulation, vertical integration and sabotage." The Journal of Industrial Economics 49.3 (2001): 319-333.

BT (2016) "Strengthening Openreach's independence: BT's Notification to Ofcom under section 89C of the Communications Act 2003 and Application to vary its Undertakings given to Ofcom pursuant to Section 154 of the Enterprise Act 2002"

Cadman, Richard. "Means not ends: Deterring discrimination through equivalence and functional separation." Telecommunications Policy 34.7 (2010): 366-374.

Cave, Martin E. "Six degrees of separation operational separation as a remedy in European telecommunications regulation." Communications \& Strategies 64 (2006): 89.

Cave, Martin, and lan Martin. "The costs and benefits of accounting separation: the Australian and British debates." Telecommunications Policy 18.1 (1994): 12-20.

Mandy, David M. "Killing the goose that may have laid the golden egg: Only the data know whether sabotage pays." Journal of Regulatory Economics 17.2 (2000): 157-172.

Mandy, David M., and David EM Sappington. "Incentives for sabotage in vertically related industries." Journal of regulatory economics 31.3 (2007): 235-260.

Ofcom (2004) "Strategic Review of Telecommunications: Phase 2 Consultation Document"

Ofcom (2005) "Final Statements on the Strategic Review of Telecommunications and Undertakings in lieu of a Reference under the Enterprise Act 2005"

Ofcom (2015) "Strategic Review of Digital Communications: Discussion Document"

Ofcom (2016a) "Making Communications work for Everyone: Initial Conclusions for the Strategic Review of Digital Communictions"

Ofcom (2016b) “Strengthening Openreach's strategic and operational independence: Proposal for comment"

Rey, Patrick, and Jean Tirole. "A primer on foreclosure." Handbook of industrial organization 3 (2007): 2145-2220.

Riordan, Michael H. "Competitive effects of vertical integration." Handbook of antitrust economics 14582 (2008). 